\title{
Goods and Service Tax - Issues and Challenges: An Analysis of Punjab, India
}

\author{
Dr. Pawan Kumar Dhiman and Seema Jain
}

\begin{abstract}
Taxes are considered as life blood of the government without which its functions would be paralyzed. To achieve goal of progress and economic development of the country it acts like a catalysts and create a roadmap to the policymakers for expansion of public and private sector of the nation like health care sector, education, Transport and public welfare etc. In India currently has a plethora of taxes both at the state as well as central government level. So, to club all these taxes under single umbrella the central government has step up to frame one tax system all over country currently known as Goods \& Services tax (GST). The present paper is an attempt to find out pros and cons of present tax system and has been found that many sectors are not satisfied with this tax system.
\end{abstract}

Keywords - Indirect Tax, GST, Vat

\section{INTRODUCTION}

For optimum allocation of country's resources well defined tax structure are needed for overall development of the nation and to diversion of funds of tax to the non-tax sectors. Tax is considered backbone and important sources of government's revenue to drive the economic growth and to achieve sustainability. The collected revenue in the shape of taxes is used to encourage developmental activities especially core areas of the economy and less developed areas of the country where investors hesitate to invest. The word 'tax' is derived from Latin word 'taxare' which means to estimate. GST is about to believe "Single rate" taxation with a myth that "One India" "One Rate".

\section{Gst Across The Globe:}

Around 160 countries in the world have already unified GST or VAT in place. To reduce tax-evasion France was the first country to implement GST in 1954 while in New Zealand introduced in 1986, Canada in 1991, in Singapore in 1994 and in Malaysia it came in to existence in 2015.Among European countries more than half percent have implemented GST except USA which provided high level of autonomy to the states. The details have been given in the following table:

It is clear from table number -01 that among Asian countries the government levied highest GST rate is in China 17 percent followed by Pakistan 16 percent in Bangladesh 15 percent and

Dr. Pawan Kumar Dhiman, Professor, Department of Management \& Humanities, Sant Longowal Institute of Engineering \& Technology, Longowal. Punjab, India

Seema Jain, Research Scholar, Department of Management \& Humanities, Sant Longowal Institute of Engineering \& Technology, Longowal. Punjab, India lowest in Japan 7 percent respectively. In case of European countries highest GST rate was in Hungry and lowest in Switzerland. In case of African countries the highest GST was in Morocco 20 percent and Madagascar 20\% lowest in Kenya 10 percent. As regards South American Countries are concerned the highest GST was in Uruguay 22\%and lowest in Brazil $10 \%$ and Paraguay $10 \%$ respectively. Data shows that GST has been implemented all over the world with small variations. Keeping in mind in our country GST taxation system have been categorized in four tax slabs: a) $5 \%$, b) $12 \%$, c) $18 \%$ and d) $28 \%$ which makes it the country of highest GST rate going past Argentina that levies 27\% tax on goods and services. The reason to levy single rate of GST in other Asian, European, African and American countries was that they don't have worry about a large and poor population like India where a majority of Indian population still resides in rural areas and is not economically sound.

\section{GST History Of India/ Conceptual framework of GST}

The tax structure of India was divided between the central government and state government. Under the central government taxes levied on income, central excise, custom duties, and service tax. While the state government levied tax including stamp duty, state excise duty, VAT (Value Added Tax), land revenue and professional tax. The existing excise duty was introduced in 1944, while the VAT laws of the states were formed during the 1950s and 60s and CST law in 1956. Numerous amendments have been made to meet the changing needs of the economy. The need to reform the existing indirect tax system in India was felt a couple of decades ago. During the era of liberalization (1991) comprehensive indirect tax legislation was the need of the hour. The idea of adopting GST was initiated by the former prime minister Atal Bihari Vajpayee Government during 2000.And an Empowered Committee (EC) was formed to create a structure for GST by the state finance ministers. The introduction date has been set on 1 April, 2010 but in July 2009 Sh Pranab Mukherjee (finance minister) announced basic skeleton of GST system. With the passage of time with some amendments in GST bill in the month of September, 2016 the Honorable President of India gave his consent for the Constitution Amendment Bill to become an Act. In 2017 four Bills related to Central GST Bill, Integrated GST Bill, Union Territory GST Bill, GST (Compensation to States) Bill with the approval in the parliament and the President's assent and GST rates and GST rules were finalized by GST council and became operational from 1 July 2017 under the leadership of Sh. Narender Modi. The introduction of Goods 
and Services Tax (GST) seems to be a very significant direction in the field of indirect tax reforms in India which would replace the existing indirect tax structure by submerging many central as well as state taxes under a roof.

TABLE-1 (GST TAX RATES OF DIFFERENT COUNTRIES )

\begin{tabular}{|c|c|c|c|c|c|}
\hline Asian Countries & $\begin{array}{l}\text { European } \\
\text { Countries }\end{array}$ & Oceania & African Countries & $\begin{array}{l}\text { South American } \\
\text { Countries }\end{array}$ & \begin{tabular}{|c|} 
Caribbean, \\
Central, And North \\
American \\
Countries
\end{tabular} \\
\hline Bangladesh $15 \%$ & Austria 20\% & Austria10\% & Algeria $17 \%$ & Argentina 27\% & Barbados $17.5 \%$ \\
\hline Srilanka $12 \%$ & Belgium $21 \%$ & $\begin{array}{c}\text { New Zealand } \\
15 \%\end{array}$ & Botswana $12 \%$ & Brazil 10\% & Canada $15 \%$ \\
\hline Pakistan $16 \%$ & Hungary $27 \%$ & Fiji 15\% & $\begin{array}{l}\text { Central African } \\
\text { Republic } 19 \%\end{array}$ & Colombia $16 \%$ & Costa Rica $13 \%$ \\
\hline Taiwan 5\% & Finland $24 \%$ & Samoa $15 \%$ & Chad $18 \%$ & Chile $19 \%$ & El Salvador $13 \%$ \\
\hline South Korea $10 \%$ & France $19.6 \%$ & & $\begin{array}{c}\text { Democratic } \\
\text { Republic of Congo } \\
16 \%\end{array}$ & Ecuador $12 \%$ & Honduras $12 \%$ \\
\hline Thailand 7\% & Germany $19 \%$ & & $\begin{array}{c}\text { Ethiopia } \\
15 \%\end{array}$ & Paraguay $10 \%$ & Jamaica $12.5 \%$ \\
\hline Singapore $7 \%$ & Russia $18 \%$ & & Egypt $10 \%$ & Peru $18 \%$ & Mexico 16\% \\
\hline China $17 \%$ & Spain $21 \%$ & & Ghana $12.5 \%$ & Uruguay $22 \%$ & \\
\hline \multirow[t]{10}{*}{ Japan 5\% } & UK $20 \%$ & & $\begin{array}{c}\text { Ivory } \\
\text { Coast } 18 \%\end{array}$ & & \\
\hline & Ireland $23 \%$ & & Kenya $10 \%$ & & \\
\hline & Netherlands 21\% & & Madagascar 16\% & & \\
\hline & Norway $25 \%$ & & Madagascar 20\% & & \\
\hline & Poland 23\% & & Malawi 16.5\% & & \\
\hline & Portugal $23 \%$ & & Mauritius $15 \%$ & & \\
\hline & Switzerland $8 \%$ & & Morocco 20\% & & \\
\hline & & & South Africa 14\% & & \\
\hline & & & Uganda $18 \%$ & & \\
\hline & & & Zimbabwe $15 \%$ & & \\
\hline
\end{tabular}




\section{LITERATURE REVIEW}

Pinki et al. (2014) in their study, "Goods and Service TaxPanacea For Indirect Tax System in India" opined that NDA government in India is positive towards implementation of GST and it is beneficial for central government, state government and as well as for consumers in long run if its implementation is backed by strong IT infrastructure.

Kumar (2014) In his research "Goods and Service Tax - A way forward" and emphasized that after implementation of GST in India many indirect tax system will be finished and there will be only one tax i.e. GST which is expected to encourage unbiased tax structure.

Sehrawat and Dhanda (2015) in their paper "GST in India: A Key Tax Reform" focused that due to dissident environment of India economy, it is demand of time to implement GST.

Anushuya and Narwal (2014) studied, "Application of CGE Modals In GST" and concluded that both GST \& CGE are very popular all over the world but GST is a powerful concept in the field of indirect taxes.

Chaurasia et al. (2016) Studied, "Role of Goods and Services Tax in the growth of Indian economy" and stressed that in overall GST will be helpful for the development of Indian economy and this will also help in improving the Gross Domestic Products of the country more than two percent.

In India GST is new concept and very less research has been one. There are number of factors which triggers the impact of GST directly or indirectly both to the consumer as well as traders and manufactures.

\section{OBJectives Of The Study}

1. To identify the impact of GST on Retail sector and various problems faced by the traders.

2. To assess the impact on consumers and to suggest remedial measures.

\section{RESEARCH MethodOLOGY AND FINDINGS}

The present research is empirical in nature and has been studied by using primary and secondary data. Survey method was followed for this study. The current study was confined to state of Punjab. Punjab is recognised as most prosperous state

TABLE-I (DEMOGRAPHICS PROFILE OF RESPONDENTS)

\begin{tabular}{|l|l|l|l|}
\hline \multirow{2}{*}{ Characteristics } & Category & $\begin{array}{l}\text { Total respondents } \\
(\mathrm{n})\end{array}$ & Percent \\
\hline \multirow{5}{*}{ Legal Entity } & Sole Proprietors & \multicolumn{1}{|c|}{40} & 62.5 \\
\cline { 2 - 4 } & Partnership & 40 & 15 \\
\cline { 2 - 4 } & Family Business & 40 & 17.5 \\
\cline { 2 - 4 } & Joint Venture & 40 & 5 \\
\hline Retail Sector & & 40 & 10 \\
\hline \multirow{3}{*}{ Average Annual Turnover } & Less than 2 lakh & 40 & 22.5 \\
\cline { 2 - 4 } & 2 lakh to 4 lakh & 67.5 \\
\cline { 2 - 4 } & More than 4 lakh & 40 & \\
\hline
\end{tabular}

Source: Field Survey and achieves rapid economic development since independence in 1947. Punjab is located in the northwest of India surrounded by Pakistan on the west, the Indian state of Jammu and Kashmir on the north, Himachal Pradesh on its northeast and Haryana and Rajasthan to its south. According to 2011 census, the population of the state was $2,77,04,236$ which was $2,43,58$, 999 out of which 62.51 percent people were living in rural area and 37.49 percept in urban area respectively and the literacy rate of the Punjab is 75.84 percent according to 2011 census. As per Economic Survey report of Punjab (2016-17) Industrial sector contributes 28.13 percent to GDP in the year 2016-17. The total Gross State Domestic Capital Formation (GSDCF) in the state is estimated for public and private sector at current prices are Rs.13166 crore and Rs. 39488 crore respectively during 2014-15. The number of large \& medium scale industrial units was 465 and 161400 small scale industrial units during the year 2015-16 (p) which would provide employment to around 11.59 lac persons, with a production value of Rs. 102300 crore tentatively. The total employment in the organized sector (both Public and Private) was 8, 55,947 out of which 4, 89,924, (57.24\%) was in the Public Sector and remaining 3, 66,023 (42.76\%) was in the private sector (2015) respectively. As per the 68th round of National Sample Survey conducted during 2011-12, the unemployment rate (usual status adjusted) in Punjab was $2.4 \%$ and the All India rate was $2.3 \%$. The main focus of the study is to find out the impact of GST on retail sector and consumers in selected areas of the state.

\section{Field survey}

To examine the impact of GST in Punjab primary data has been collected by using structured questionnaires from 40 retailers of four cities such as Barnala, Sangrur, Longowal and Nabha. The secondary data was collected from various sources i.e. annual reports, journals, books, articles, websites newspapers etc. the details of respondents has been given in the following table.

\section{Source: Field Survey}


TABLE -II: (IMPACT OF GST ON RETAIL SECTOR)

\begin{tabular}{|c|c|c|c|c|c|c|}
\hline Sr.No. & Impact & $\begin{array}{l}\text { Sample } \\
\text { size } \\
\text { (n) }\end{array}$ & $\begin{array}{l}\text { Response } \\
\text { (in percent) }\end{array}$ & Mean & $\begin{array}{l}\text { Standard } \\
\text { Deviation }\end{array}$ & $\begin{array}{l}\text { Standard } \\
\text { Error }\end{array}$ \\
\hline 1. & $\begin{array}{l}\text { GST reduces material cost and } \\
\text { comparing with sales tax. }\end{array}$ & 40 & 40 & 2.3076 & 1.1266 & 0.1781 \\
\hline 2. & Decrease in operating cost & 40 & 52.5 & 3.1025 & 1.1872 & 0.1877 \\
\hline 3. & Filling GST is complicated & 40 & 55 & 3.3589 & 1.1980 & 0.1894 \\
\hline 4. & GST improves revenue & 40 & 50 & 2.8974 & 0.9841 & 0.1556 \\
\hline 5. & $\begin{array}{l}\text { Uniformity of tax rates in neighbouring } \\
\text { states become helpful }\end{array}$ & 40 & 62.5 & 3.7435 & 1.2516 & 0.1979 \\
\hline 6. & GST difficult to understand & 40 & 65 & 3.8461 & 1.1266 & 0.1781 \\
\hline 7. & Will help to increase business & 40 & 57.5 & 3.5641 & 1.1980 & 0.1894 \\
\hline 8. & Have knowledge of filling return online & 40 & 30 & 2.4871 & 0.9577 & 0.1514 \\
\hline 9. & Take help from concerned departments & 40 & 35 & 2.4871 & 1.2585 & 0.1989 \\
\hline 10. & $\begin{array}{l}\text { Higher tax burden for manufacturing } \\
\text { SMEs/business }\end{array}$ & 40 & 40 & 2.6666 & 1.3165 & 0.2081 \\
\hline 11. & Extra staff required & 40 & 60 & 3.0769 & 1.3774 & 0.2177 \\
\hline 12. & Still not clear about GST & 40 & 72.5 & 3.2307 & 1.7179 & 0.2716 \\
\hline 13. & Training to be imparted & 40 & 90 & 4.0769 & 1.0250 & 0.1620 \\
\hline 14. & Fill GST self & 40 & 40 & 2.2564 & 1.0669 & 0.1687 \\
\hline 15. & $\begin{array}{l}\text { Current taxation system (GST) remain } \\
\text { complex }\end{array}$ & 40 & 60 & 2.7179 & 1.1668 & 0.1844 \\
\hline 16. & Will reduce Tax burden & 40 & 55 & 2.7179 & 1.3116 & 0.2073 \\
\hline 17. & Hired Charted accountant/ accountant & 40 & 72.5 & 3.1794 & 1.7216 & 0.2722 \\
\hline 18. & $\begin{array}{l}\text { Do you think all businesses need to be } \\
\text { registered under GST? }\end{array}$ & 40 & 90 & 3.8974 & 1.3435 & 0.2124 \\
\hline 19. & $\begin{array}{l}\text { Do you see a rise in the demand for your } \\
\text { services by clients? }\end{array}$ & 40 & 57.5 & 2.8717 & 1.1591 & 0.1832 \\
\hline
\end{tabular}

Source: personal prove survey

It is evident from table- 1 that out of total surveyed respondents 62.5 percent having business as sole proprietorship, 15 percent in partnership, 17.5 were engaged in family business and 5 percent were in joint ventures respectively. As regards turnover of the businesses were concerned out of total surveyed units 10 percent of the units having turn- over less than 2 lac annually, 22.5 percent ranging between 2 lac to 4 lac and 67.5 percent having more than 4 lac respectively. Data also depicts that after implementing GST both consumers as well as traders are facing some problems as information provided by them the details have been shown in following table.

It is clear from table- 2 that there were some positive as well as negative impacts after implementing of GST in the state. Data reveals that72.5 respondents clarified that GST is not clear, 40 percent responded GST increases the material cost than sales tax,55 online filling of tax in GST system is complicated for 55 percent respondents but GST also helpful to reduce tax burden , 50 percent respondents also agree that the
GST also helpful to improve revenue of the business. Only 52 percent respondents told GST will be helpful in decreasing operating cost. Due to uniformity of tax structure in the neighbouring states inter-state business would create a positive impact. For 65 percent respondents GST is difficult to understand and they required the help from the concerned department related to GST. On the other side 57percent respondents GST take positively as GST would increase the business and according to 90 percent respondents every business should register under the GST, According to 60 makes current taxation system is also complex. 30 percent respondents told that they had the knowledge of filling return online otherwise they had to hire charted Accountant at exorbitant charges to fill return online. All over the world taxes are collected to run their respective government. Without money no nation can accelerate. To develop Indian well defined tax structure is need of the hour some collected information has been shown in table number 4 . 
TABLE-III (IMPACT OF GST ON CONSUMERS)

\begin{tabular}{|l|l|l|l|l|l|l|}
\hline Sr.No. & Impact & $\begin{array}{l}\text { Sample } \\
\text { size } \\
(\mathrm{n})\end{array}$ & $\begin{array}{l}\text { Yes } \\
\text { (in percent) }\end{array}$ & Mean & $\begin{array}{l}\text { Standard } \\
\text { Deviation }\end{array}$ & $\begin{array}{l}\text { Standard } \\
\text { Error }\end{array}$ \\
\hline 1 & $\begin{array}{l}\text { GST increases the overall cost for } \\
\text { consumers. }\end{array}$ & 40 & 62.5 & 3.564103 & 1.320208 & 0.208743 \\
\hline
\end{tabular}

Source: Field survey

TABLE-IV IMPACT OF GST ON ECONOMY

\begin{tabular}{|c|l|l|l|l|l|l|}
\hline Sr.No. & Impact & $\begin{array}{l}\text { Sample } \\
\text { size } \\
(\mathrm{n})\end{array}$ & $\begin{array}{l}\text { Yes } \\
\text { (in percent) }\end{array}$ & Mean & $\begin{array}{l}\text { Standard } \\
\text { Deviation }\end{array}$ & $\begin{array}{l}\text { Standard } \\
\text { Error }\end{array}$ \\
\hline 1. & GST will increase tax collection & 40 & 92.5 & 3.974 & 1.285 & 0.203 \\
\hline 2. & $\begin{array}{l}\text { Do you think, implementation of } \\
\text { GST will cause higher price of goods }\end{array}$ & 40 & 60 & 3.385 & 1.181 & 0.187 \\
\hline 3. & $\begin{array}{l}\text { GST checks the tax evasion } \\
\text { periodically. }\end{array}$ & 40 & 67.5 & 3.692 & 1.236 & 0.195 \\
\hline 4. & $\begin{array}{l}\text { Do you think India is ready for } \\
\text { implementing GST system? }\end{array}$ & 40 & 45 & 2.308 & 1.127 & 0.178 \\
\hline 6. & \begin{tabular}{l} 
Do you think GST is a fair tax? \\
\hline
\end{tabular} & 40 & 77.5 & 3.103 & 1.187 & 0.188 \\
\hline
\end{tabular}

Source: Field survey

It is clear from above table that GST would increase the tax collection and also helpful in national development. Out of total surveyed respondents 92.5 percent respondents agreed that GST will increase government revenues in the shape of tax collection, 67.5 percent told it will check the tax evasion periodically, 77.5 percent respondents told GST is a fair tax practice whereas 40 percent respondents admitted India is ready for implementing GST system and 60 percent viewed implementation of GST will cause higher price of goods.

Table number 3 depicts that the burden of GST ultimately borne by the consumer and the result they have to pay more.

\section{Advantages Of Gst}

GST has been envisaged as an efficient tax system, neutral in its application and distributionally attractive. By following the GST transparency system, there are quite a lot of advantages that include:

1. After implementing GST in India number of procedures / services such as registration, returns, payments etc. would be available online would be helpful to the taxpayers, to comply the rules in transparent manner.

2. After GST there would be Common national market throughout the country leading to high scope of tax planning and manipulation practices to avoid/ reduce taxes.

3. Reduction in transaction costs of doing business would eventually lead to an improved competitiveness for the trade and industry.

4. GST, with fewer and simplified legislations, has the potential to reduce the number of litigations. Furthermore, reduced number of compliance and self-assessment can also reduce the queries and objections raised by the department on day-to-day basis leading to lower number of litigations.

5. After implementation of new tax regime, the possibilities of job expansion in the Indian economy has been increased. And need for jobs in the formal sectors such as automobiles, logistics, e-commerce, consultancy, skilled accountants and tax consultants have increased substantially.

6. Under GST, there would be only one tax from the manufacturer to the consumer, leading to transparency of taxes paid to the final consumer.

\section{DisadVantages Of Gst}

1. In the real sense a one nation one tax is in spirit only. Because when a person has to do business in two states he has to take GST number in each state separately which is troublesome to the businessmen.

2. After implementing GST it is multiple tax rate system i.e there are 7 standard tax rates and multiple rates of cess provided for various goods and services which only open the Pandora box of classification disputes and unnecessary confusion.

3. It was observed that it was implementation in hurry without discussing with stakeholders who created a mass resentment among the businessmen and consumers due to various range of taxes.

4. GST is also having three types of taxes and all have to be maintained and this not going too easy for small Businessman.

\section{SUGGESTIONS}

- Filing of 37 returns per GSTIN is very time consuming exercise, complex, cumbersome and regressive. Where in everyone would not even have the bandwidth to comply with. It 
is suggested that procedure be made simple and training centres be opened by the government at block level to provide training to all those are involved in filling GST returns on nominal payment basis.

- To become global player in the global market and to strengthen 'Make in India' initiative, GST rates should be fixed as per international standard and indigenously viable.

- Composition scheme must be given to small scale operators and particularly reduced processes should be applicable to them. And proposed limit for registration Rs. 4 lakh for North East and Rs. 9 lakh for others that should be common for entire country along with different slab system for dealing with similar products with different range all corner of the country.

\section{CONCLUSION}

Since independence developing countries like India has adopted mixed economy and care has to be taken to promote capital formation and investment both in public and private sector. To boost the economy GST is the most logical step which is expected that the malicious activity of tax theft will go away. The transition to the GST regime benefits both governments as well as the consumer. India was a union of 29 small tax economies and 7 union territories where GST is one of the biggest taxation reforms in India which is to integrate State economies and boost overall growth. GST will create a single, unified Indian market by dividing the taxation burden equitably between manufacturing and services. Introduction of a GST to replace the existing multiple tax structures of Center and State taxes would make it possible to give full credit for inputs taxes collected. GST, being a destination-based consumption tax will be reshaping India's indirect tax structure. The transparent character of GST would also make Indian products competitive in the domestic and international markets.

\section{REFERENCES}

[1]F. George, "GST - In and Out: The Indian Framework" pp.: 468-471).

[2]S. K. Maity,. "Impacts Of GST (Goods And Service Tax) In India (First Series Book 1)" pp 353-358.

[3]J. Hiregange,. "India GST for Beginners: 2nd Edition" White Falcon Publishing. pp. 164-166).

[4]Pinki, SupriyaKamna, RichaVerma (2014), "Good and Service Tax: Panacea for Indirect Tax System in India", "Tactful Management Research Journal”, vol.2, Issue 10, July2014

[5]N. Kumar (2014): "Goods and service tax in India- A way forward”, "Global Journals of multidisciplinary studies", vol.3, issue 6, may 2014.

[6]P. chaurasia, S. Singh, P. Kumar Sen (2016), "Role of Goods and Service Tax in the growth of Indian economy", "International journal of science technology and management”, vol.5, issue 2, February 2016.

[7]M. Sehrawat, U. Dhanda (2015), "GST in India: A key tax reform", "International journal of research granthaalayah", vol.3, issue 12, December 2015.

[8]Financial Express, New Delhi | Published: July 1, 2017 4:05 PM

[9]Economic Survey, Government of Punjab. 2016-17

[10] https://www.indiatoday.in/pti-feed/story/punjab-may-suffer-financial-lo ss-with-gst-state-fm-487995-2016-01-13.

[11] http://www.egstax.in/2017/03/impact-of-goods-and-service-tax.html

[12] https://www.businessalligators.com/gst-impact-rates-type-conclusion/

[13] http://www.news18.com/news/business/punjab-lost-40-per-cent-revenue s-after-gst-implementation-minister-1635023.html

[14] http://www.cityairnews.com/content/punjab-pradesh-beopar-mandal-su bmits-memo-ludhiana-detc-jk-jain-seeking-clarifications-gst.

[15] Crud, Zale. Importance and Role of Taxation. From https://www.scribd.com /document/274984014.

[16] Clarice Jobeth R. Kee. The Importance of Taxes to the Government and the Economy. From https://www.scribd.com/document/192453869 